\title{
Bezpieczeństwo energetyczne Polski w latach 2010-2016 w świetle prostego modelu importu netto
}

Honorata Nyga-Łukaszewska*

\section{Wstęp}

Energia jest podstawą rozwoju gospodarki, zarówno w ujęciu makro, mezo, jak i mikro. Do zagadnień związanych z rynkiem energii na wszystkich tych poziomach należą: bezpieczeństwo energetyczne, zarządzanie popytem na energię, internalizacja negatywnych efektów zewnętrznych będących skutkiem działalności branży energetycznej czy w szerszym znaczeniu - ochrona klimatu. Szczególnego znaczenia w ostatnich latach nabrała problematyka, między innymi, bezpieczeństwa energetycznego. Rola analizy tego zjawiska wzrosła w szczególności w kontekście przerw w dostawach surowców zagranicznych.

Przedmiotem rozważań w niniejszym tekście jest szeroko pojmowana problematyka bezpieczeństwa energetycznego. Analiza obejmuje wpływ zmian cen surowców energetycznych na rynkach międzynarodowych na PKB importera. W tym znaczeniu zagadnienie nawiązuje do klasycznych definicji bezpieczeństwa energetycznego, w których centrum zainteresowania stanowiły szoki cenowe na rynkach surowców energetycznych.

Ze względu na znaczne uzależnienie Polski od importowanych surowców energetycznych (ropy naftowej i gazu ziemnego), zasadne wydaje się badanie, którego celem byłoby określenie wpływu zmian cen tych surowców na PKB. Analiza obejmuje lata 2010-2016. W ujęciu przedmiotowym badanie dotyczy produktów energetycznych na poziomie agregacji odpowiadającym kategoriom stosowanym przez Główny Urząd Statystyczny (dalej: GUS). Z tego powodu, aby określić przedmiot badań, autorka zamiennie używa w tekście pojęć „energia”

\footnotetext{
* Honorata Nyga-Łukaszewska - doktor, adiunkt, Szkoła Główna Handlowa w Warszawie, Kolegium Gospodarki Światowej, hlukas@sgh.waw.pl.
} 
i „surowce energetyczne”, mając jednak świadomość, że „energia” to pojęcie szersze, obejmujące zarówno energię pierwotną, jak i wtórną, a surowce energetyczne są źródłem energii pierwotnej.

Niniejsze opracowanie podzielono na pięć części. Wprowadzeniem do tekstu jest wstęp opisujący cel badania, jego strukturę, źródła danych i podstawowe pojęcia. Kolejny element to analiza teoretyczna opisująca problematykę bezpieczeństwa energetycznego w świetle doniesień naukowych. W części trzeciej skupiono się na podmiocie badań - Polsce jako importerze energii. W kolejnej sekcji opisano metodologię i wyniki badania. Tekst zamykają wnioski z analizy oraz wyjaśnienia jej ograniczeń badawczych.

Tekst przygotowano na podstawie studiów literaturowych oraz analizy empirycznej. W części obliczeniowej wykorzystano dane GUS.

\section{Bezpieczeństwo energetyczne - ujęcie teoretyczne}

Bezpieczeństwo energetyczne należy do relatywnie młodych i słabo zdefiniowanych koncepcji naukowych. Świadczy o tym wiele prac badawczych, w których pojęcie opisywane jest jako jest trudne do zdefiniowania (Kruyt i in. 2009, s. 609), niejasne (Checchi, Behrens i Egenhofer 2009, s. 1665) czy takie, któremu brakuje jednej, wspólnej definicji w środowisku badawczym (Garcia-Gusano, Iribarren i Garrain 2017). Dowodem niesłabnącego zainteresowania badaczy tą problematyką jest fakt, że tylko pomiędzy 2001-2014 powstały 104 opracowania (naukowe, branżowe, specjalistyczne) na ten temat (Ang, Choong \& Ng 2015, s. 1078). Ang, Choong i Ng twierdzą, że wspomniana literatura prezentuje 83 definicje tego zjawiska (Ang, Choong \& Ng 2015, s. 1078). Wydaje się, że jednym z powodów tej różnorodności ujęć teoretycznych jest interdyscyplinarność zjawiska i posługiwanie się zróżnicowanym, często niekorespondującym ze sobą aparatem pojęciowym (Nyga-Łukaszewska 2018). Dlatego w rozważaniach teoretycznych autorka koncentruje się na ekonomicznym aspekcie bezpieczeństwa energetycznego w jego klasycznym wydaniu - poświęconym szokom cenowym na rynkach energii.

Współczesna koncepcja bezpieczeństwa energetycznego sięga kryzysów naftowych XX wieku. W centrum zainteresowania badaczy w tym okresie znalazła się problematyka wpływu wzrostu cen ropy naftowej na gospodarki krajów ją importujących. Wywołane przez wydarzenia polityczne szoki podażowe na rynkach energii stworzyły zatem nową koncepcję - bezpieczeństwo energetyczne. W centrum zainteresowania badaczy znalazły się kwestie oszacowania wpływu zmian cen ropy naftowej na zmienne makroekonomiczne. W tym nurcie znajdują się m.in. prace: Mork i Hall 1979, Sauter i Awerbuch 2003, Huntington 2004, Sumskis 2015. Jak podaje Sumskis (Sumskis 2015, s. 121), praca Mork i Halla jest jedną z pierwszych, które podejmowały tę problematykę. Niemniej jednak 
kwestia ta była już wcześniej analizowana przez innych badaczy (Mork i Hall 1979, s. 2). Mork i Hall (Mork i Hall 1979) wpisują się w nurt badań, w którym analizuje się to, jak zmiany cen energii wpłynęły na następujące zmienne: PKB, zatrudnienie, inwestycje czy inflację. Konstruując model dla USA, doszli do wniosku, że w wyniku wzrostu cen ropy naftowej w roku 1974 PKB tego kraju zmniejszyło się o 2\%, zaś w 1975 - o 5\%. Z kolei Sauter i Awerbuch (Sauter i Awerbuch 2003), prezentując obszerny przegląd literatury przedmiotu, podsumowują, że 10-procentowy wzrost cen ropy naftowej hamuje tempo wzrostu PKB o $0,6-2,5 \%$. Autorzy podkreślają również, że zmiany PKB obserwowane były z opóźnieniem (od trzech do nawet siedmiu kwartałów) po wzroście cen ropy. Podobnie obszerne zestawienie literatury prezentują Alistair i Hunt (Arnold i Hunt 2009), którzy zawężają swoją analizę do krajów rozwiniętych i strefy euro. Posługują się przy tym również publikacjami uznanych instytucji międzynarodowych, takich jak Międzynarodowy Fundusz Walutowy, Bank Światowy czy Międzynarodowa Agencja Energetyczna. W obszarze rozważań znajdują się nie tylko zmiany PKB, ale również poziom inwestycji, inflacji i saldo bilansu handlowego.

Odnosząc te rozważania do współczesnych nurtów badań nad bezpieczeństwem energetycznym, można stwierdzić, że wpisują się one w aspekt cenowy tego zjawiska (Cherp i Jewell 2014), który ilustruje koszt importowanych paliw. Jest to jednak jeden $\mathrm{z}$ wielu elementów badań nad bezpieczeństwem energetycznym, do których można zaliczyć m.in. kwestię ochrony klimatu (Frei 2004) czy liberalizację rynków energii (Wright 2005).

\section{Polska jako importer energii}

W bilansie energii pierwotnej Polski przeważają paliwa kopalne, zarówno te stałe (węgiel), jak i płynne (węglowodory). Dominacja węgla wynika z posiadania bogatych złóż tego surowca i relatywnie rozwiniętej branży górniczej w kraju. Pomimo że Polska należy do znaczących producentów i eksporterów węgla na świecie, jego produkcja stale się zmniejsza. W 1978 roku wydobycie węgla w Polsce wynosiło 128 Mtoe $^{1}$, a w 2015 - 54 Mtoe (IEA 2017, s. 19). Dlatego też udział węgla w bilansie energii pierwotnej zmalał z 79\% w 1985 roku do 51\% w 2015 roku (IEA 2017, s. 121).

Węgiel jest również podstawowym surowcem wykorzystywanym w Polsce do produkcji energii elektrycznej. W 2015 roku ponad 80\% energii pochodziło z węgla, w tym $48 \%$ - kamienny i $33 \%$ - brunatny. W tym samym okresie odnawialne źródła energii (OZE) miały 13-pocentowy udział w produkcji elektryczności. Udział węgla w produkcji energii elektrycznej stopniowo maleje. W latach 19752005 oscylował między 92\% (1975, 1985, 2005) a 97\% (1995) (IEA 2017, s. 121).

${ }^{1}$ Mtoe - miliony ton oleju ekwiwalentnego. Jednostka energii. 
Wykres 1. Bilans energii pierwotnej Polski w 2015 roku według poszczególnych paliw

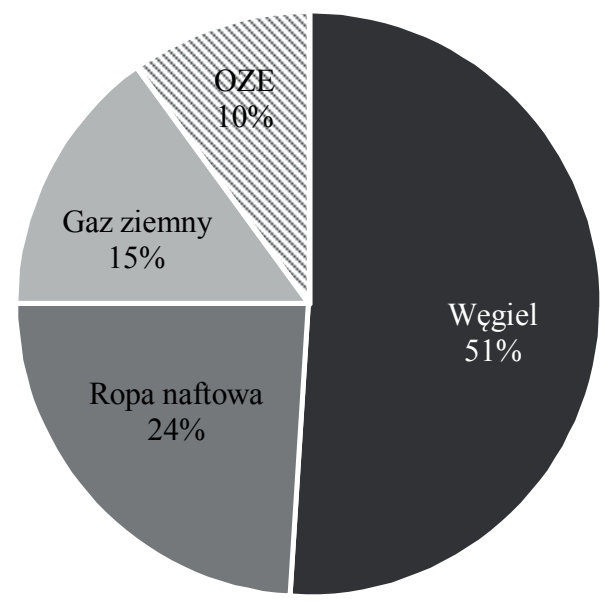

Źródło: opracowanie własne na podstawie IEA 2017, s. 19.

Stale zmniejszające się wydobycie węgla spowodowało, że w 2008 roku Polska po raz pierwszy stała się importerem tego surowca netto. Większość zagranicznego węgla w 2015 roku pochodziła z Rosji (60\%) i Australii (19\%).

Wykres 2. Eksport, import i saldo w międzynarodowym handlu węglem kamiennym Polski w latach 2010-2016

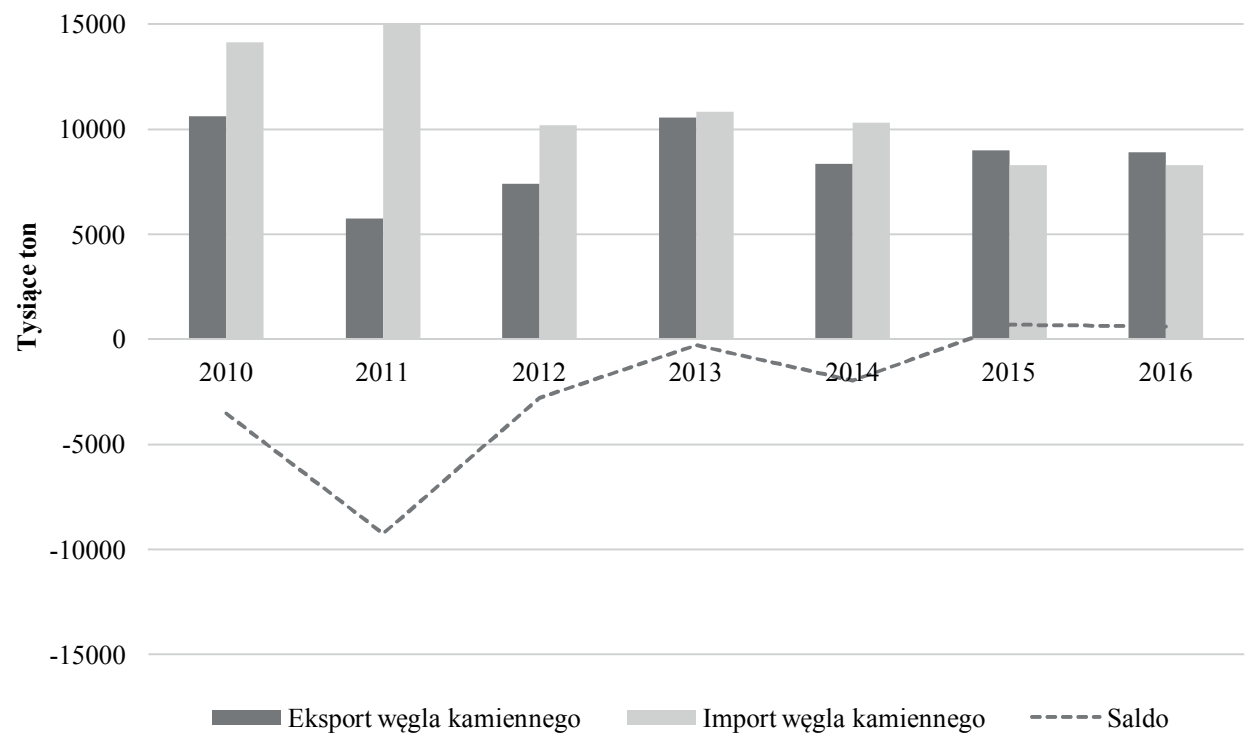

Źródło: opracowanie własne na podstawie: NETTG.PL, pozyskano z: http://nettg.pl/news/143511/ gornictwo-afera-z-importem-od-putina-czy-tylko-medialna-burza, 9.02.2018. 
Sytuacja zmieniła się na korzyść Polski w 2015 roku, kiedy ponownie stała się eksporterem węgla netto (IEA 2017, s. 122-123). Ponieważ przedmiotem obrotów międzynarodowych jest jedynie węgiel kamienny (Polska 2015: 97\% importu, 98\% eksportu), przedstawione poniżej dane dotyczą tylko tego surowca.

Ropa naftowa jest drugim po węglu najważniejszym surowcem w bilansie energii pierwotnej Polski. Ze względu na znikomą produkcję krajową $(0,9 \mathrm{mln} \mathrm{t}$ - 2015), prawie całość surowca pochodzi z importu (1125,9 mln $\mathrm{t}-2015)$ (GUS 2016, s. 24). Głównym dostawcą jest Rosja, z której trafiło do Polski 88\% importowanej ropy naftowej w 2015 roku (IEA 2017, s. 158). Ropa naftowa jest wykorzystywana głównie przez przemysł petrochemiczny.

Tabela 1. Import ropy naftowej do Polski w 2015 roku według krajów

\begin{tabular}{|l|c|}
\hline Kraj & Udział w imporcie ropy naftowej do Polski w 2015 roku (w \%) \\
\hline Rosja & 88,00 \\
\hline Irak & 6,80 \\
\hline Kazachstan & 1,89 \\
\hline Arabia Saudyjska & 1,54 \\
\hline Norwegia & 1,29 \\
\hline Litwa & 0,18 \\
\hline
\end{tabular}

Źródło: opracowanie własne na podstawie IEA 2017, s. 158.

Gaz ziemny, wykorzystywany jest zarówno przez odbiorców indywidualnych, jak i przemysłowych. W tej drugiej grupie przeważają zakłady przemysłu chemicznego, które mają 45-procentowy udział w popycie na gaz w Polsce (2015). Zapotrzebowanie na gaz ziemny (wysokometanowy) pokrywane jest $\mathrm{w} 1 / 3$ produkcją krajową $\left(1995,5 \mathrm{mln} \mathrm{m}^{3}\right.$ - 2015), a w 2/3 importem (11 458,3 $\mathrm{mln} \mathrm{m}^{3}$ - 2015) (GUS 2016, s. 23). W strukturze importu dominuje Rosja z 72-procentowym udziałem (2015) (IEA 2017, s. 140).

\section{Metodologia}

Badanie opiera się na tzw. prostym modelu importu netto, który został zaprezentowany przez Bank Światowy w grudniu 2005 roku (Davis i in. 2005). Za jego pomocą oszacowano to, jak wzrost cen energii wpływa na PKB Ukrainy. Narzędzie to jest stosowane również przez Program ds. Rozwoju Organizacji Narodów Zjednoczonych. Bank Światowy koncentruje się w swoich szacunkach na rynku ukraińskim ze względu na jego dużą zależność od importowa- 
nych surowców. Model pokazuje, jak zmiana cen energii, przy określonej jej elastyczności cenowej², wpływa na PKB. Formuła przedstawia się następująco:

$\% \triangle P K B=\% \triangle T T *(1-E) * \frac{- \text { Import netto }}{P K B}$

$\% \triangle \mathrm{PKB}$ - procentowa zmiana PKB

$\% \Delta \mathrm{TT}$ - procentowa zmiana terms of trade ${ }^{3}$

E - elastyczność cenowa popytu (moduł)

Badanie Banku Światowego ma dwuletni horyzont - lata 2005-2006. Zakłada się, że w tym okresie nastąpił wzrost cen importowanych surowców. Analiza prowadzona jest na bazie pięciu różnych scenariuszy, które różnią się skalą wzrostu cen surowców oraz tym, czy wzrost dotyczy tylko jednego, czy obu importowanych surowców.

Badanie będące przedmiotem autorka przeprowadza na przykładzie Polski. Badanie nie jest prowadzone w hipotetycznym ujęciu scenariuszowym ex ante, lecz w ujęciu ex post. Horyzont badań obejmuje, podobnie jak w przypadku Ukrainy, krótki okres. Dodatkowo w przypadku Ukrainy szacunki uwzględniają analizę dwóch różnych surowców: gazu ziemnego i ropy naftowej. Przedmiotem niniejszego badania jest energia w rozumieniu standardowej klasyfikacji handlu międzynarodowego (ang. SITC - standard international trade classification) autorstwa ONZ. Przez pojęcie energii rozumie się tutaj kategorię obejmującą paliwa mineralne, smary i materiały pochodne. W jej skład wchodzą węgiel, brykiet, ropa i produkty ropopochodne, gaz ziemny (naturalny i przetworzony) oraz energia elektryczna.

Agregacja danych na tak wysokim poziomie wynika z możliwości jej porównania $\mathrm{z}$ istniejącymi danymi dotyczącymi cen w handlu międzynarodowym. GUS podaje terms of trade, m.in. dla kategorii SITC, bez wyróżniania poszczególnych rodzajów energii. Nie ma w nich rozróżnienia na energię pierwotną i wtórną ani na poszczególne paliwa (gaz, ropa). Dlatego do przeprowadzenia analizy ex ante niezbędne było zapewnienie porównywalności danych. Autorka ma jednak świadomość tego, że tak wysoki poziom agregacji danych może wpływać na otrzymywane wyniki. Próbą zdyskontowania tego efektu jest przyjęcie różnych poziomów elastyczności cenowej popytu na energię.

Problematyka ta jest szeroko dyskutowana w literaturze przedmiotu. Nie brakuje prac, w których szacuje się elastyczność cenową popytu na energię z wyszczególnieniem jej rodzajów, odbiorców, okresu analizy (krótki, długi)

\footnotetext{
${ }^{2}$ Elastyczność cenowa popytu lub podaży opisuje zmiany popytu lub podaży wskutek zmian cen.

${ }^{3}$ Terms of trade - tzw. relacje wymienne. Wyróżnia się kilka rodzajów terms of trade: towarowe, dochodowe, jednoczynnikowe, dwuczynnikowe. Najprostsze towarowe terms of trade „są najczęściej używanym miernikiem zmian cen w handlu międzynarodowym". Do obliczeń w niniejszym tekście wykorzystuje się towarowe terms of trade. Budnikowski (2006), s. 78.
} 
czy regionów geograficznych (Liu 2004, s. 12-13). Według badań Liu (2004) elastyczność cenowa popytu w krajach OECD w krótkim i długim okresie dla gospodarstw domowych jest wyższa (w ujęciu względnym) niż w przemyśle. Wynika to $\mathrm{z}$ tego, że gospodarstwa domowe mają większą elastyczność w dostosowywaniu się do zmian cen niż zakłady przemysłowe. W naturalny sposób wraz z czasem popyt staje się coraz bardziej elastyczny względem ceny w obu grupach odbiorców.

Różnice w elastyczności cenowej popytu na energię są widoczne nie tylko w przypadku odbiorców, ale również wewnątrz kraju. Ten aspekt, z uwagi na uwarunkowania geograficzne, badany jest głównie w odniesieniu do rynku USA, np.: pomiędzy stanami lub hrabstwami (Bernstein i Griffin 2006, s. 11)4.

Tabela 2. Elastyczność cenowa popytu na wybrane źródła energii w krótkim i długim okresie dla gospodarstw domowych i przemysłu w krajach OECD

\begin{tabular}{|l|c|c|}
\hline Paliwo/źródło energii & Gospodarstwa domowe & Przemysł \\
\hline \multicolumn{3}{|c|}{ Krótki okres } \\
\hline Elektryczność & $-0,030$ & $-0,013$ \\
\hline Gaz ziemny & $-0,102$ & $-0,067$ \\
\hline Węgiel kamienny & 0,00 & 0,162 \\
\hline \multicolumn{3}{|c|}{ Długi okres } \\
\hline Elektryczność & $-0,157$ & $-0,044$ \\
\hline Gaz ziemny & $-0,364$ & $-0,243$ \\
\hline Węgiel kamienny & 0,001 & 0,589 \\
\hline
\end{tabular}

Źródło: opracowanie własne na podstawie Liu 2004, s. 12-13.

Interesujące zestawienie dotyczące elastyczności cenowej i dochodowej popytu przedstawia Międzynarodowy Fundusz Walutowy. Ze względu na przedmiot badania w tym miejscu omawia się jedynie elastyczność cenową popytu. Powołując się na dotychczasowe badania, autorzy pracy MFW twierdzą, że w przypadku ropy naftowej elastyczność popytu względem ceny waha się od $-0,02$ w krótkim okresie do $-0,86$ czy nawet $0 \mathrm{w}$ długim. Ta sama wartość w przypadku benzyny w długim okresie wynosi ok. $-0,30$ do 0 , a w przypadku elektryczności $-0,25$ do $-0,5$. Oznacza to, że popyt na ropę naftową czy benzynę jest nieelastyczny względem ceny lub sztywny (gdy 0).

${ }^{4}$ Szerzej na ten temat piszą Bernstein i Griffin 2006. 
Tabela 3. Elastyczność cenowa popytu na wybrane źródła energii w krótkim i długim okresie

\begin{tabular}{|l|c|c|}
\hline Paliwo/źródło energii & $\begin{array}{c}\text { Elastyczność cenowa } \\
\text { popytu w krótkim okresie }\end{array}$ & $\begin{array}{c}\text { Elastyczność cenowa } \\
\text { popytu w długim okresie }\end{array}$ \\
\hline Ropa naftowa & $-0,02$ do $-0,07$ & $-0,86$ do 0 \\
\hline Benzyna & - & $-0,30$ do 0 \\
\hline Elektryczność & - & $-0,25$ do $-0,5$ \\
\hline
\end{tabular}

Źródło: opracowanie własne na podstawie Charap, da Silva, Rodriguez 2013, s. 4.

Przedstawione szacunki ilustrują oba zjawiska w ujęciu poszczególnych paliw, co stanowi dla przedmiotowego badania istotne ograniczenie $\mathrm{z}$ uwagi na poziom agregacji danych. W 1999 roku Międzynarodowa Agencja Energii (MAE) w badaniu poświęconym efektom eliminacji subsydiów na emisję $\mathrm{CO}_{2}$ przyjęła w swoich badaniach elastyczność cenową energii na poziomie od $-0,25$ do $-0,5$. Przyjęty zakres elastyczności był efektem przeprowadzonego wśród ekspertów badania metodą delficką (IEA 1999, s. 84). Ze względu na duże rozbieżności pomiędzy estymowanymi elastycznościami cenowymi popytu w niniejszym badaniu zdecydowano się wykorzystać zakres wartości proponowany przez MAE.

Dane dotyczące cen energii zostały, podobnie jak statystyki importu netto, zagregowane do poziomu sekcji trzeciej SITC (opisanej powyżej). Wydaje się, że przyjęcie takiego rozumowania w przypadku Polski właściwie odzwierciedla ceny eksportowanych i importowanych surowców. W strukturze importu energii przeważają węglowodory i ich pochodne, zaś w eksporcie (w wybranych latach) węgiel. Znaczenie energii elektrycznej w strukturze podaży i popytu Polski na energię ogółem jest marginalne (IEA 2017, s. 11, 75). O tym, jak znaczącą pozycję w polskim imporcie odgrywają węglowodory, świadczy fakt, że w 2015 roku ponad połowę wartości importu stanowiła ropa, a 1/5 - gaz ziemny (IEA 2017, s. 21).

Terms of trade dla kategorii ,paliwa mineralne, smary i materiały pochodne” Polski w latach objętych analizą (2010-2016) zmieniały się od 97,5 do 109,3. Najmniej korzystna relacja cen utrzymywała się w latach 2010-2012, kiedy ceny importowanej ropy naftowej znacząco wzrosły. W 2010 roku za baryłkę zagranicznej ropy Polska płaciła 77,9 USD, rok później - 109,6 USD, a w 2011 - 111 USD, podążając tym samym za ogólnoświatowym trendem (OECD 2018). Ten okres pokrywa się ze spadkiem cen węgla energetycznego na rynkach światowych, który stanowi produkt eksportowy Polski. Jednoczesny wzrost cen towarów importowanych i spadek cen towarów eksportowanych przełożył się na pogorszenie relacji wymiennych Polski w trzeciej sekcji SITC. Odwrotna sytuacja miała miejsce począwszy od 2014 roku. Spadek cen ropy w 2015 roku i relatywnie niezmienne ceny węgla energetycznego spowodowały, że terms of trade Polski tylko w tej grupie poprawiły się w stosunku do roku poprzedniego. 
Wykres 3. Terms of trade Polski w kategorii ,paliwa mineralne, smary i materiały pochodne” w latach 2010-2016

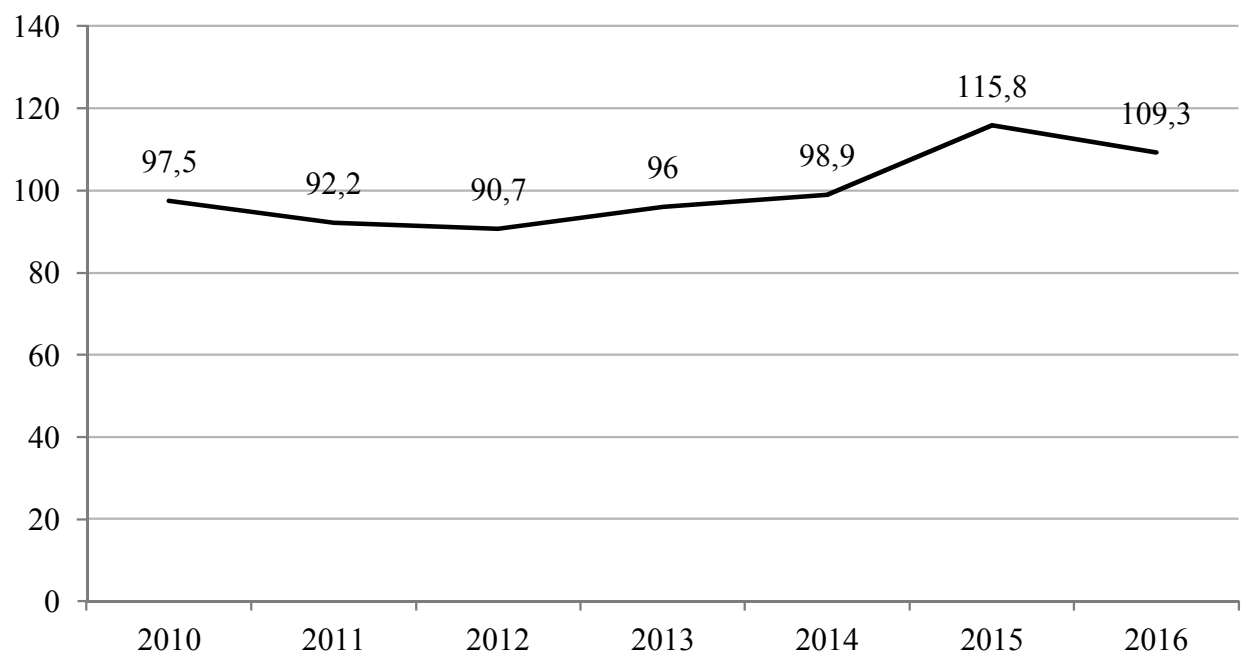

— Terms of trade, kategoria „paliwa mineralne, smary i materiały pochodne”

Źródło: opracowanie własne na podstawie Roczników Handlu Zagranicznego GUS 2010-2017.

Dane ilustrujące import netto stanowią różnicę pomiędzy importem a eksportem w kategorii ,paliwa mineralne, smary i materiały pochodne”. Import netto przyjmuje wartości ujemne, gdy eksport przewyższa import, a wartości dodatnie - w sytuacji odwrotnej. Z uwagi na strukturę tej kategorii statystycznej w całym analizowanym okresie import netto był ujemny. Na wykresie 2 wyraźnie widać, że najgłębsze zmiany w imporcie netto pokrywają się z okresami, w których ceny ropy naftowej były najwyższe. Należą do nich lata 2011-2014, kiedy ceny ropy oscylowały wokół $100 \mathrm{USD} /$ baryłkę . Wraz ze spadkiem cen ropy w 2015 roku ujemne saldo importu netto zmniejszyło się. Cena ropy naftowej jest w tym przypadku istotnym wyznacznikiem cen wszystkich importowanych do Polski węglowodorów, w tym gazu ziemnego. Wiąże się to z tym, że ceny gazu ziemnego w kontraktach międzynarodowych indeksowane są o ceny ropy naftowej z różnym opóźnieniem czasowym. Z tego powodu na ujemne saldo w kategorii ,paliwa mineralne, smary i materiały pochodne" wpływają głównie wysokie ceny ropy naftowej.

Wykorzystane w badaniach dane o PKB Polski pochodzą z baz GUS i są podawane w PLN, w cenach bieżących. Statystyki obejmują szacunki zrewidowane.

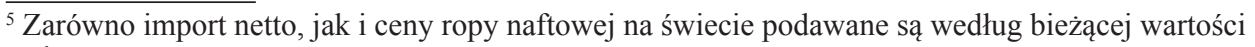
waluty. 
Wykres 4. Import netto Polski w kategorii „paliwa mineralne, smary i materiały pochodne” (mln PLN, ceny bieżące) oraz cena ropy naftowej (USD/baryłka, ceny bieżące) w latach 2010-2016

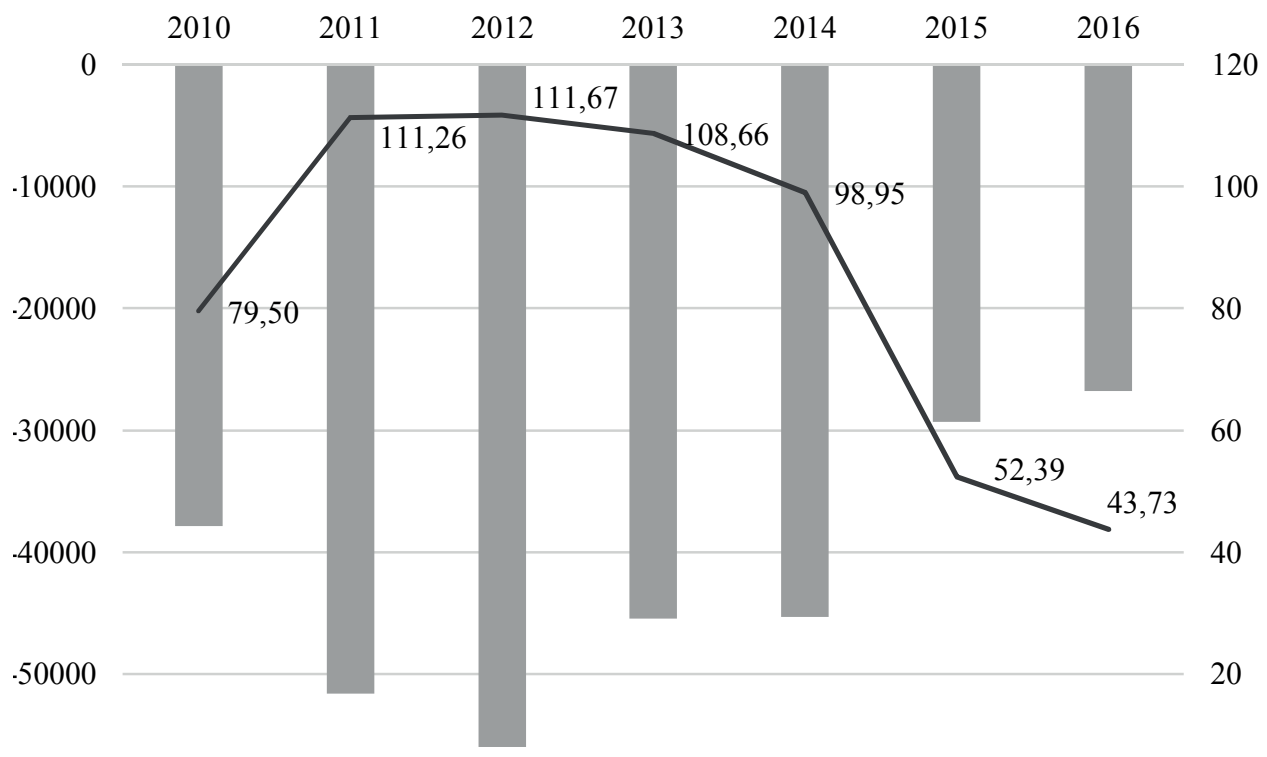

.60000

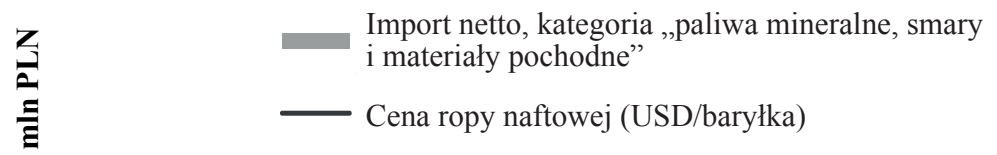

Źródło: opracowanie własne na podstawie Roczników Handlu Zagranicznego GUS 2010-2017 oraz BP Statistical Review of World Energy 2017.

Zastosowanie prostego modelu importu netto do analizy zmian międzynarodowych relacji wymiennych w stosunku do importu energii netto i PKB Polski w latach 2010-2016 pokazuje, że poprawie terms of trade towarzyszył wzrost PKB. Poprawa relacji wymiennych oznacza wartości większe od 100, a pogorszenie mniejsze od 100. Wynika to $\mathrm{z}$ faktu, że w przypadku towarowych terms of trade poprawa wiąże się z uzyskiwaniem wyższych cen w eksporcie niż w imporcie. Pogorszenie wynika $\mathrm{z}$ kolei ze wzrostu cen importowanych towarów. Poprawa terms of trade $\mathrm{w}$ latach 2015-2016 przyczyniła się do wzrostu PKB o $0,15 \%-0,1 \%$. Z kolei pogorszenie relacji wymiennych w okresie 2010-2014 zmniejszyło PKB Polski o wartości z zakresu od 0,24\% (2012) do 0,02\% (2014) - przy elastyczności cenowej popytu-0,25 oraz od $0,16 \%$ (2012) do $0,01 \%$ (2014) - przy elastyczności -0,5. Pokazuje to, że wzrost cen ropy naftowej w latach 2011-2014 miał negatywny wpływ na PKB Polski. Z kolei spadek cen ropy od 2015 roku i relatywnie niezmienne ceny węgla energetycznego oddziaływały pozytywnie na PKB Polski. 
W świetle otrzymanych wyników można postawić hipotezę o tym, że za zmiany polskiego PKB w analizowanym okresie odpowiadają głównie zmiany cen ropy naftowej. Jest to przypuszczenie, ponieważ na podstawie sposobu szacowania zmian PKB w modelu Banku Światowego i wykorzystanych w tym celu danych GUS trudno wyizolować zmiany terms of trade w odniesieniu do poszczególnych surowców energetycznych, np. węgla czy ropy naftowej. Niemniej jednak szacowanie zmian PKB z użyciem terms of trade określonej grupy towarowej w SITC zamiast wykorzystania ogólnych terms of trade danego kraju w większym stopniu kalibruje otrzymywane wyniki. Dla przykładu: w przypadku elastyczności na poziomie - 0,25 PKB Polski w 2012 roku obliczone przy użyciu terms of trade Polski zmniejszyłoby się o ok. $0,13 \%$ nie zaś, jak w zaprezentowanym badaniu, o $0,24 \%$. Z kolei w 2014 roku, przy tych samych założeniach, nie zaobserwowano by żadnych zmian polskiego PKB $(0,00 \%)$; podczas gdy w wyniku wykorzystania terms of trade kategorii ,paliwa mineralne, smary i materiały pochodne" PKB zmniejsza się o $0,02 \%$.

Wykres 5. Zmiana PKB Polski (w \%) w odniesieniu do zróżnicowanych poziomów elastyczności cenowej popytu na paliwa mineralnych, smary i materiały pochodne w latach 2010-2016

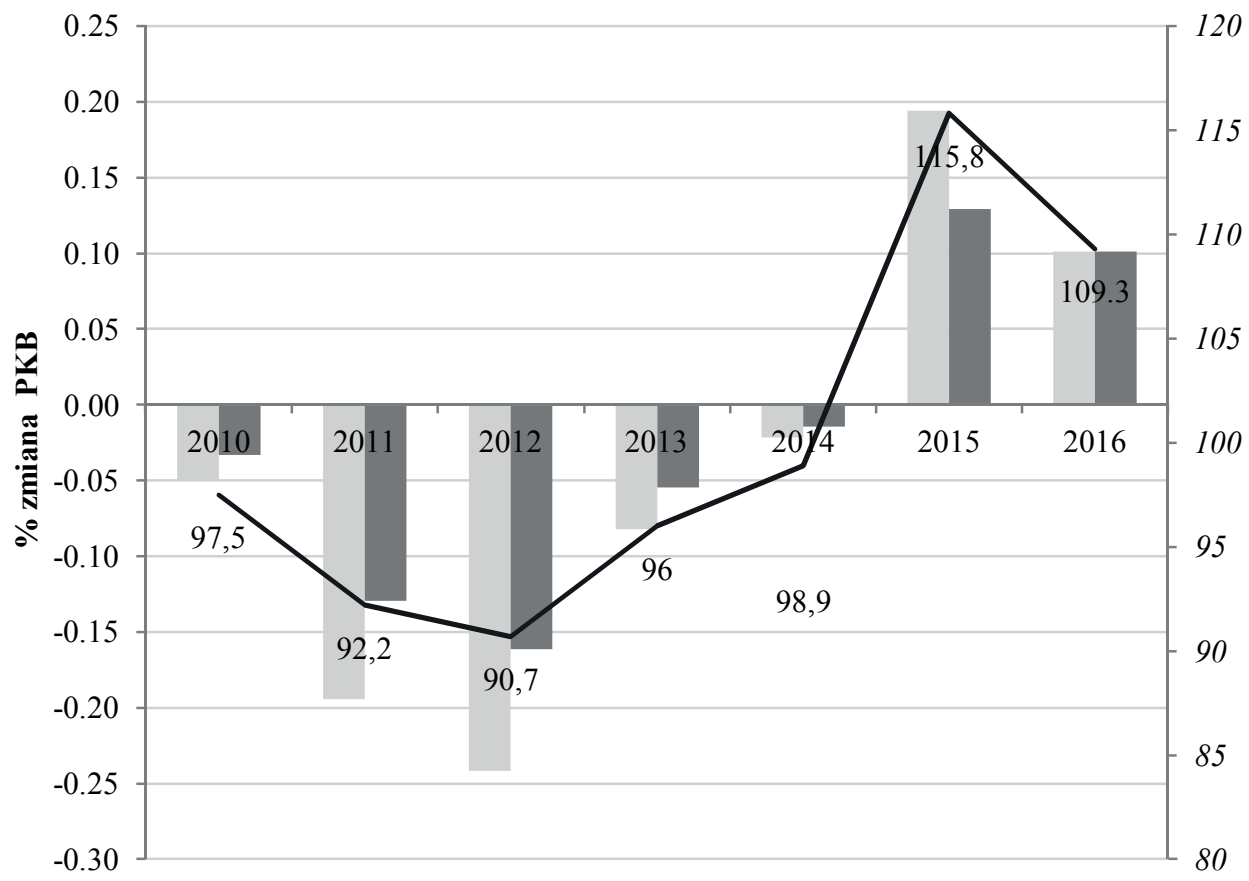

Wynik przy elastyczności -0,25 Wynik przy elastyczności -0,5 - Terms of trade

* Pochyłym drukiem zaznaczono wartości osi terms of trade, tak aby były one bardziej czytelne na wykresie.

Źródło: opracowanie własne. 
Mając na uwadze konstrukcję prostego modelu importu netto Banku Światowego, można stwierdzić, że zarówno zmiany poziomu elastyczności, jak i poziom agregacji towarowych terms of trade wpłynie na osiągnięty wynik. Szacowanie zmian PKB w zakresie elastyczności cenowej popytu wskazanej przez MAE daje jednak pewną gwarancję, że nawet dezagregacja kategorii SITC „paliwa mineralne, smary i lubrykanty" dałaby podobne wyniki.

Można jednak przypuszczać, że zmiany cen ropy naftowej mają znacznie większy wpływ na PKB niż zmiany cen gazu ziemnego. Ropa naftowa, a przede wszystkim jej pochodne charakteryzują się monokulturowym wykorzystaniem w branży transportowej i nie mają one upowszechnionych, konkurencyjnych cenowo substytutów, dlatego popyt jest mało elastyczny. W przypadku gazu ziemnego istnieje wiele substytutów w przypadku większości jego zastosowań. Dotyczy to m.in.: transportu, ogrzewania i przygotowywania posiłków. Gaz ziemny konkuruje z ropą naftową, węglem czy biomasą. Pomimo jego powiązania z cenami ropy zmiany PKB byłyby mniej intensywne ze względu na większą elastyczność cenową popytu. Gdyby dezagregacja danych umożliwiła przygotowanie oddzielnych szacunków dla gospodarstw domowych i przedsiębiorstw, mogłoby się okazać, że ze względu na mniej elastyczny popyt w drugiej z wymienionych grup odbiorców zmiany byłyby również mniej intensywne.

\section{Podsumowanie}

Badanie pokazuje kosztowy aspekt bezpieczeństwa energetycznego. Jest to klasyczny nurt w badaniach nad tym zjawiskiem, którego początki związane były z kryzysami naftowymi końca lat siedemdziesiątych i osiemdziesiątych XX wie$\mathrm{ku}$. Szoki podażowe na rynkach ropy naftowej wzbudziły zainteresowanie badaczy z powodu ich wpływu na zmienne makroekonomiczne. Takie spojrzenie na bezpieczeństwo energetyczne jest szczególnie istotne dla krajów importujących energię. Pokazuje ono, jak zmiany cen energii wpływają na gospodarkę kraju. Przypadek Polski, uzależnionej od importu węglowodorów oraz będącej w przeważającej części okresu 2010-2016 importerem węgla netto, jest dobrym punktem wyjścia takiej analizy.

Do obliczeń zaprezentowanych w opracowaniu wykorzystano prosty model importu netto autorstwa Banku Światowego. Narzędzie to bada zmiany PKB w zależności od terms of trade, PKB, importu netto, uwzględniając elastyczność cenową popytu. Szacunki Banku Światowego wykonywane były ex ante oddzielnie dla każdego z paliw. Przedmiotem niniejszego badania była analiza ex post dla grup towarowych obejmujących m.in. surowce energetyczne. Towary zagregowane zostały do kategorii trzeciej SITC, obejmującej węgiel, ropę naftową, gaz ziemny i energię elektryczną. Okres analizy uwzględniający lata 
2010-2016 jest podyktowany chęcią uwzględnienia faktu, że Polska była importerem węgla netto oraz zaprezentowania jak najbardziej aktualnych danych statystycznych.

Wykorzystane w badaniu empirycznym dane pochodziły z baz GUS. W badaniu przyjęto poziomy elastyczności cenowej popytu na energię za Międzynarodową Agencją Energetyczną, wahające się od $-0,5$ do $-0,25$. Mimo że popyt jest nieelastyczny w tym przedziale, nawet niewielkie jego zmiany przyczyniają się do wahań PKB. Dla importera energii każdy okres wzrostu jej cen na rynkach międzynarodowych wiązał się z pogorszeniem terms of trade (towarowych), zaś spadek - z ich poprawą. Dlatego spadek terms of trade Polski w latach 20102014, przy założonych poziomach elastyczności cenowej popytu, przekładał się na spadek PKB o $0,1-0,2 \%$. Odwrotne zmiany wywołała poprawa terms of trade Polski w latach 2015-2016.

Przedstawione badanie, ze względu na sposób jego przeprowadzenia i przyjęte założenia, ma swoje ograniczenia. Po pierwsze, nie jest analizą prognostyczną, a historyczną - pokazującą zmiany PKB w reakcji na zmiany terms of trade. Po drugie, przyjęcie innego podmiotu badań spowoduje zmianę wyników. Jest to nawiązanie do silnej kontekstualności zjawiska bezpieczeństwa energetycznego (Kruyt i in. 2009, s. 2166) i jego krajowej specyfiki (Knox-Hayes i in. 2013). Po trzecie, przyjęcie innego niż założony zakres elastyczności cenowej popytu również zmieni otrzymane wyniki. Częściowo wiąże się to z kolejnym ograniczeniem badania, które dotyczy agregacji danych na poziomie kategorii SITC. Można spodziewać się, że dezagregacja do poszczególnych paliw lub nawet grup odbiorców przyniosłaby bardziej dokładne szacunki. Byłoby to szczególnie widoczne w długim okresie, który umożliwiłby podmiotom dostosowanie się do ceny (uelastycznienie popytu). Wszystkie przedstawione ograniczenia wskazuje się jako dalsze kroki badawcze.

\section{Bibliografia}

Alistair H., Steve A. (2009), National and EU-Level Estimates of Energy Supply Externalities, nr 186/April, CEPS Policy Brief, http://aei.pitt.edu/10815/ /1/1834-1.pdf (data dostępu: 30.01.2018).

Bernstein M., Griffin J. (2006), Regional Differences in the Price-Elasticity of Demand for Energy, National Renewable Energy Laboratory, Santa Monica, CA. BP (2017), BP Statistical Review of World Energy.

Budnikowski A. (2006), Międzynarodowe Stosunki Gospodarcze, Polskie Wydawnictwo Ekonomiczne, Warszawa.

Charap J., Silva A. da, Rodriguez P. (2013), Energy Subsidies and Energy Consumption - A Cross-Country Analysis, „IMF Working Paper”, nr 13/112. 
Checchi A., Behrens A., Egenhofer Ch. (2009), Long-Term Energy Security Risks for Europe: A Sector-Specific Approach, „CEPS Working Document”, nr 309.

Cherp A., Jewell J. (2014), The concept of energy security: Beyond the four As, „Energy Policy”, nr 75.

Davis M., Piontkivsky R., Pindyuuk O., Ostojic D. (2005), Ukraine - The impact of higher natural gas and oil prices, „Working Paper”, Washington, World Bank, $\mathrm{nr}$ 38602, http://documents.worldbank.org/curated/ en/838301468173971844/Ukraine-The-impact-of-higher-natural-gas-andoil-prices (data dostępu: 30.01.2018).

Frei Ch. (2004), The Kyoto Protocol - a victim of supply security? or: if Maslow were in energy politics, „Energy Policy”, nr 32.

Garcia-Gusano D., Iribarren D., Garrain D. (2017), Prospective analysis of energy security: A practical lice-cycle approach focused on renewable power generation and oriented towards policy-makers, „Applied Energy”, $\mathrm{nr} 190$.

GUS (2016), Energia 2016, Główny Urząd Statystyczny, https://stat.gov.pl/files/ gfx/portalinformacyjny/pl/defaultaktualnosci/5485/1/4/1/energia2016.pdf (data dostępu: 30.01.2018).

Huntington H. (2004), Shares, gaps and the economy's response to oil disruptions, „Energy Economics”, nr 26(3).

IEA (1999), World Energy Outlook 1999. Looking at Energy Subsidies: Getting the Prices Right, Paris, IEA, www.worldenergyoutlook.org/media/weowebsite/2008-1994/weo1999.pdf (data dostępu: 30.01.2018).

IEA (2017), Energy Policies of IEA Countries. Poland 2016 Review, Paris, www. iea.org/publications/freepublications/publication/Energy_Policies_of_IEA_ Countries_Poland_2016_Review.pdf (data dostępu: 30.01.2018).

Knox-Hayes J., Brown M., Sovacool B., Wang Y. (2013), Understanding attitudes toward energy security: Results of a cross-national survey, „Global Environmental Change, $\mathrm{nr} 23$.

Kruyt B., Vuuren D. van, de Vries H., Groenenberg H. (2009), Indicators for energy security, „Energy Policy”, nr 37.

Liu G. (2004), Estimating Energy Demand Elasticities for OECD Countries A Dynamic Panel Data Approach, Discussion Papers.

Mork K., Hall R. (1979), Energy Prices, Inflation, and Recession, 1974-1975, „NBER Working Paper”, nr 369, www.nber.org/papers/w0369.

NBP (2015), Międzynarodowy handel ustugami w 2014 r., www.nbp.pl/statysty$\mathrm{ka} / \mathrm{dwn} / \mathrm{mhu}$-info.pdf (data dostępu: 30.01.2018).

NETTG.PL (2017), Górnictwo: afera z importem od Putina, czy tylko medialna burza?, http://nettg.pl/news/143511/gornictwo-afera-z-importem-od-putina-czy-tylko-medialna-burza (data dostępu: 30.01.2018).

Nyga-Łukaszewska H. (2018), Bezpieczeństwo energetyczne: u źródet chaosu semantycznego (w:) Gryz J., Podraza A., Ruszel M. (red.), Bezpieczeństwo 
energetyczne. Koncepcje - wyzwania - interesy, Wydawnictwo Naukowe PWN, Warszawa.

OECD (2018), Crude oil import prices (indicator), DOI: 10.1787/9ee0e3ab-en. Rocznik Handlu Zagranicznego Polski 2013, Główny Urząd Statystyczny. Rocznik Handlu Zagranicznego Polski 2016, Główny Urząd Statystyczny. Rocznik Handlu Zagranicznego Polski 2017, Główny Urząd Statystyczny.

Sauter R., Awerbuch S. (2003), Oil price volatility and economic activity: A survey and literature review, IEA Research Paper.

Sumskis V. (2015), Economic implications of energy security in the short run, „Ekonomika”, nr 94 (3).

Wright P. (2005), Liberalisation and the security of gas supply in the UK, „Energy Policy", nr 33.

\section{Streszczenie}

Zagadnienia związane $\mathrm{z}$ rynkiem energii są istotnym elementem polityki gospodarczej każdego kraju. Jednym z nich jest kwestia bezpieczeństwa energetycznego. Studia literaturowe wskazują na bogactwo wysiłków definiujących to zjawisko. Przedmiotem szczególnej analizy w tekście jest jego klasyczne ujęcie, w którego centrum zainteresowania znajdują się szoki cenowe na rynkach paliw. Z powodu silnego uzależnienia Polski od importowanych paliw (ropy naftowej i gazu ziemnego) zasadne wydaje się podjęcie badania, którego celem byłoby określenie wpływu zmian cen importowanych surowców na PKB. Analiza obejmuje lata 2010-2016, a w badaniu korzysta się z prostego modelu importu netto autorstwa Banku Światowego. Przeprowadzona analiza pokazuje, że każdy okres wzrostu cen energii na rynkach międzynarodowych wiązał się z pogorszeniem terms of trade (towarowych), zaś spadek $-\mathrm{z}$ ich poprawą. Dlatego spadek terms of trade dla Polski w latach 2010-2014 przełożył się na spadek PKB o 0,1-0,2\%.

Słowa kluczowe: bezpieczeństwo energetyczne, terms of trade, import energii

\section{Summary}

Polish energy security in 2010-2016 from the perspective of the simple net import model

Issues related to the energy market are an important element of the economic policy of each country. One such issue is energy security. A literature review reveals broad energy security definitions. The classical approach to energy security, which focuses on price shocks in fuel markets, is the subject of special analysis in the text. Due to the high dependence of Poland on imported fuels (oil and 
gas), it seems reasonable to undertake a study aimed at determining the impact of changes in the prices of imported energy on GDP. The scope of the analysis covers the years 2010-2016. The study uses a simple net import model presented by the World Bank. The analysis shows that each period of energy price growth on international markets was associated with a deterioration of Polish terms of trade (goods), and a decrease in price growth with their improvement. That is why the decrease of terms of trade for Poland in 2010-2014 translated into a GDP decline of $0.1-0.2 \%$.

Keywords: energy security, terms of trade, energy import

JEL: Q31, Q37, Q43 